Maria A. Burganova Doctor of Art, Professor,

Full member of the Russian Academy of Arts, Head of the Monumental and Decorative Sculpture Department at Moscow State Stroganov Academy of Industrial and Applied Arts e-mail:dom.text@gmail.com

Russia, Moscow

ORCID 0000-0002-8695-9743

ResearcherID C-9437-2017

Julia A. Smolenkova

$P h D$, associate professor

Moscow State Stroganov Academyof Industrial and Applied Art e-mail: JSmolenkova@gmail.com

Russia, Moscow

ORCID 0000-0003-4746-7057

ResearcherID AAB-2212-2019

DOI: 10.36340/2071-6818-2020-16-1-19-37

\title{
Alexander Burganov: a New Code of Time and Space
}

Summary: The article is devoted to the analysis of the work of Alexander Burganov, an outstanding contemporary sculptor and graphic artist. The study of the categories of Space and Time on the example of his works is the main theme of the article. The author believes that Time and Space in Burganov's work are unique categories and correspond to reality least of all; the author gives examples of specific works and convinces that Burganov has modeled a bright, recognizable, unique personal code with the help of sculptures, graphic works, texts, installations, and artistic gestures. Today, this is especially noticeable as the culture of the $21^{\text {st }}$ century has sharpened and almost brought to a logical conclusion the awareness of artistic being, formed in the second half of the $20^{\text {th }}$ century, and is now on the verge of new creative realities leading to conceptual discoveries in art. The author believes that the artist keenly captures the invisible waves emitted by the developing cultures and subcultures of the $21^{\text {st }}$ century, in which a body devoid of naturalistic sensuality is coldly and symbolically akin to antique statues.

The author pays great attention to the analysis of new materials in Burganov's creative work, believing that the $21^{\text {st }}$ century has brought great changes not only to the form but also to the substance of the bodies of statues and sculptural compositions. Marble is replaced with plastic, bronze coexists with gypsum, metal meshes surround voids and follow the movements of the wind. Paper on an iron frame is a rightful hero of this 


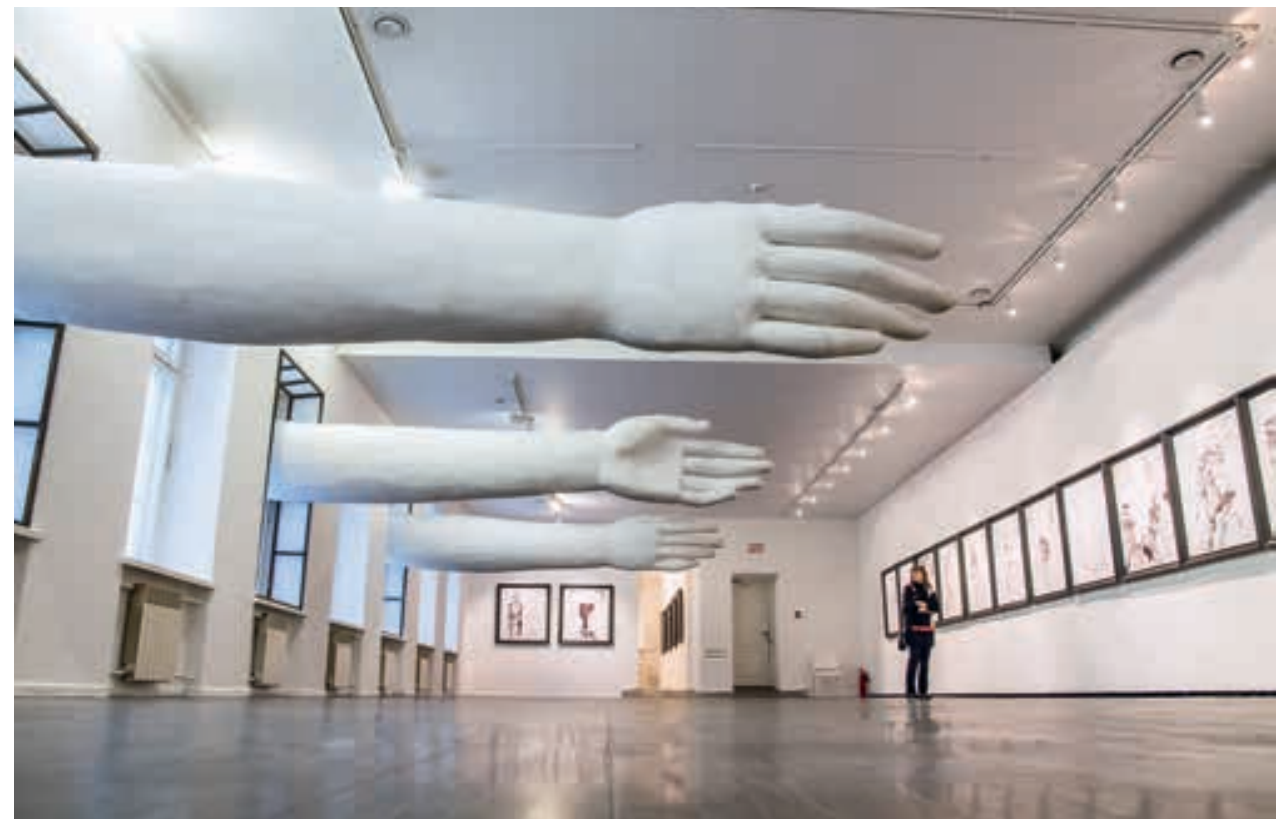

Ill. 1. A Meeting. Installation in the Moscow Museum of Modern Art. Clay, iron. 2016

"Olympus". It should be noted that there is no place for imitation. New material dictates its conditions for shaping and participates in the interpretation of a new image.

Analyzing the contemporary space of culture, the author states that the experiences of European crises have brought into art restraint and minimalism, democracy and the idea of some kind of universal permissiveness in creating and judging art. However, the predominance of mass culture, which received a completely new face and opportunity owing to the virtual space spilled over reality, was the main marker of the culture of the early $21^{\text {st }}$ century. Today, a mixture of styles and cultures, a combination of incongruous is a new reality introduced into our lives by virtual culture. The author emphasizes that it was this invisible space that Alexander Burganov could feel and has reflected in his work. This has made his works relevant and understandable to a new generation which almost does not feel the classics. The author concludes that Alexander Burganov's work has become a kind of bridge connecting the worlds of classics and modernity, high and grassroots culture, myths and reality.

Keywords: Alexander N. Burganov, sculptor, space, time, culture, art, author's style.

Alexander Burganov ${ }^{1}$ is a master who has created a special universe with his spatial coordinates and time, flowing in accordance with his creative plan. In his art, time and space are unique categories corresponding to reality least of all. He has modeled a bright, recognizable, unique personal code with the help of sculptures, graphic works,

1. Alexander Nikolaevich Burganov (1935) - Russian sculptor, academician of the Russian Academy of Arts, People's Artist of Russia. Burganov's artworks are kept in the collections of major Russian and foreign art museums. The Moscow State Museum Burganov House is dedicated to his work. 


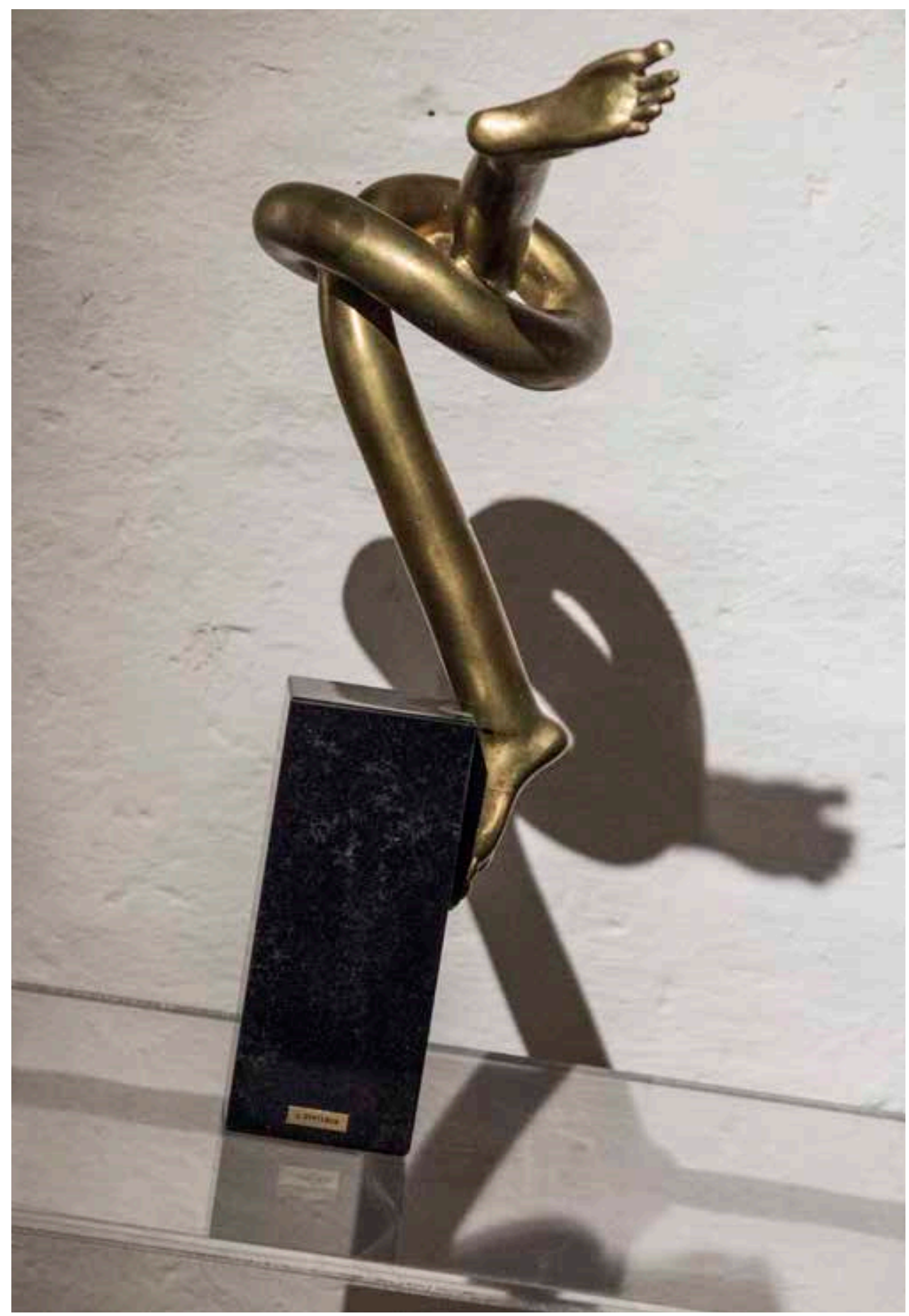

Ill. 2. A Knot. Bronze, granite. 2000 


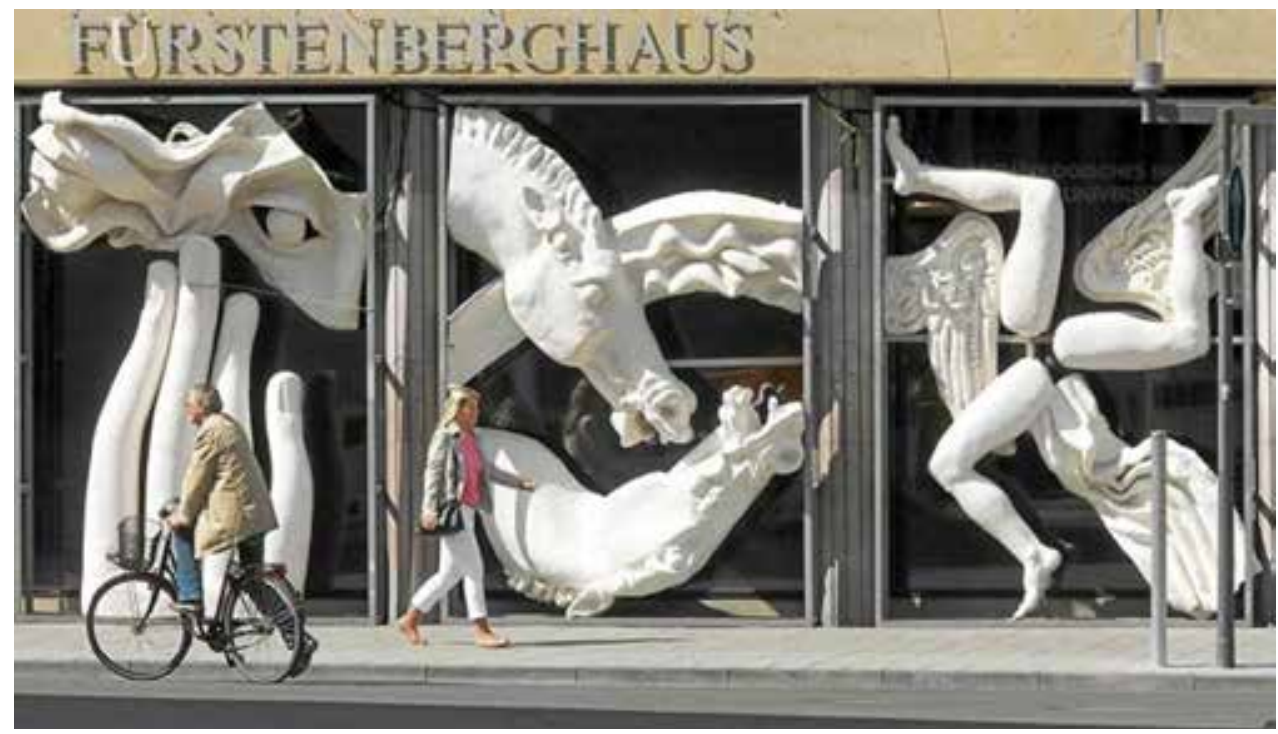

Ill. 3. The Trojan War. Clay, metal. 2013. The composition was created specifically for Alexander Burganov's personal exhibition at the Wilhelm Museum of Archeology of the University of Westphalia in Münster. 2013

texts, installations, and artistic gestures. Today, this is especially noticeable as the culture of the $21^{\text {st }}$ century has intensified and almost brought to a logical conclusion the awareness of artistic life, formed in the second half of the $20^{\text {th }}$ century, and is now on the verge of new creative realities leading to conceptual discoveries in art.

Sculpture has always been associated with reflecting a person and creating his or her ideal image. Alexander Burganov has also built his ideal in figurative sculpture. On the one hand, parting with reality is seen in it as in antique sculpture. The artist sensitively captures the invisible waves of a new culture emitted by developing cultures and subcultures in which a body devoid of naturalistic sensuality is coldly and symbolically akin to antique statues. A form abstracted to the ideal plays the main role. Burganov's muses are harmonious, like ionic columns; in the formation of figures he is more interested in the architectonics of shaping than in body sensuality. The symbolism of images allows the body to be freely interpreted. Hands can exist separately and multiply, creating a gesture necessary for the $\operatorname{artist}^{2}$ (ill. 1). Legs are knotted ${ }^{3}$ (ill. 2), run in a circle $^{4}$ (ill. 3), even become a portrait ${ }^{5}$.

The sculptor creates compositions using the collage method, combining differentsized elements, quotes, freely interpreting the form, strung on each other and intersecting

2. A Meeting. Installation in the Moscow Museum of Modern Art. Clay, iron. 2016.

3. A Knot. Bronze, granite. 2000.

4. The Trojan War. Clay, metal. 2013. The composition was created specifically for Alexander Burganov's personal exhibition at the Wilhelm Museum of Archeology of the University of Westphalia in Münster. 2013.

5. Portrait of a Stranger. Bronze. 1980. 


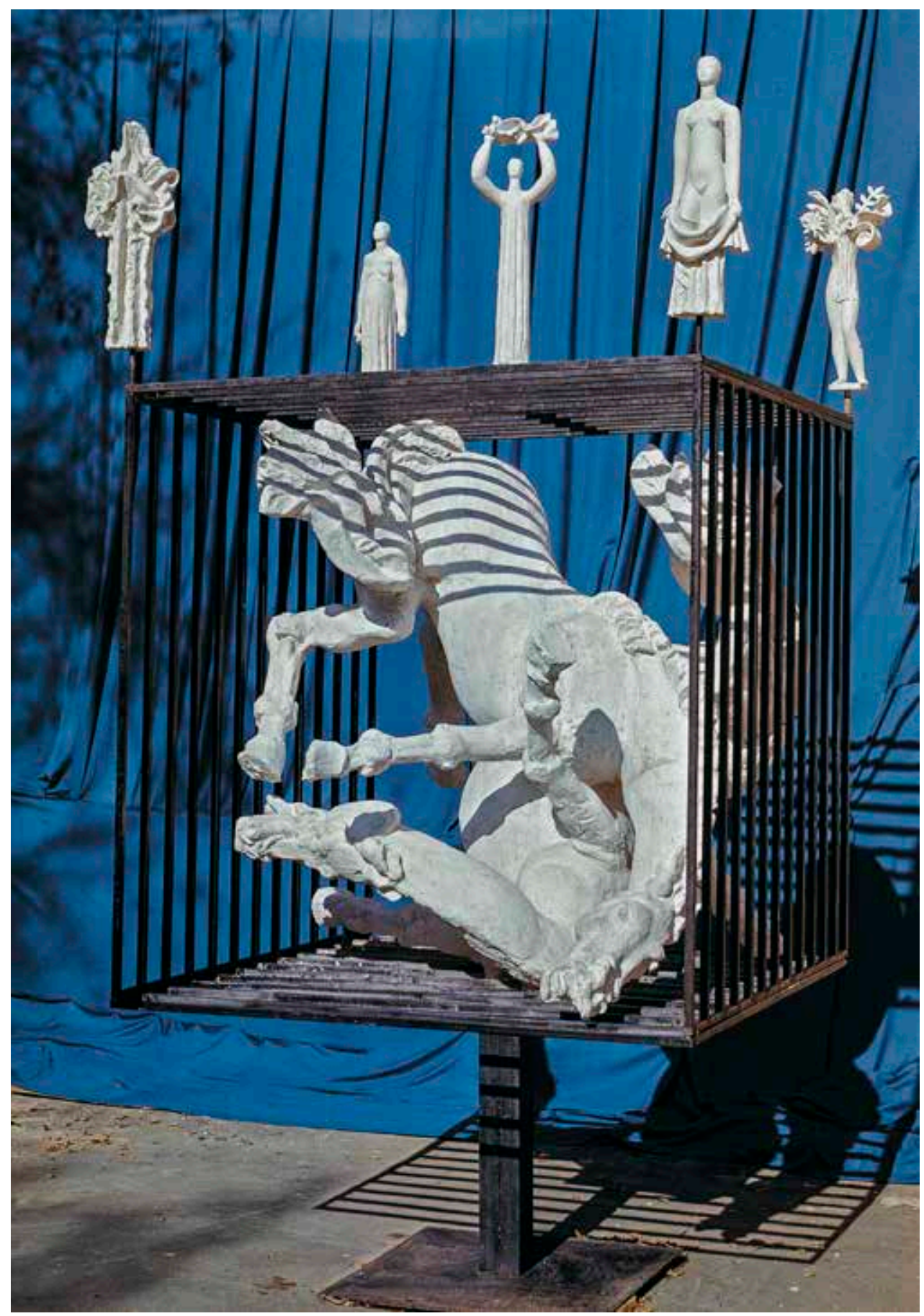

Ill. 4. War and Peace. Bronze, metal, 1980. The composition was installed in Aachen in front of the European Congress Hall by P. Ludwig 


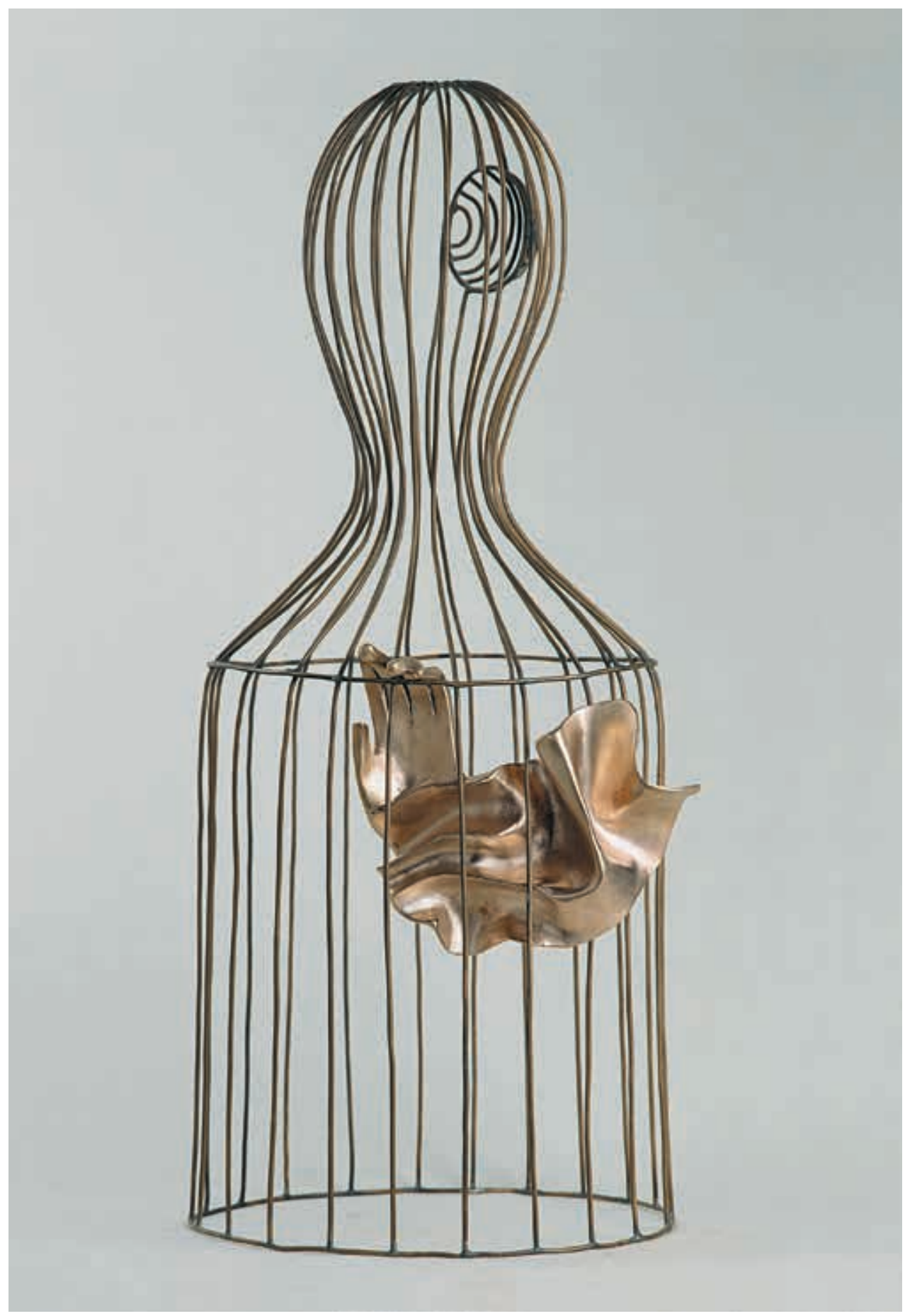

Ill. 5. Alexander Burganov. A Cage, 1988. Bronze. $171 \times 75 \times 62$ 
spatial and temporal layers. In the War and Peace composition ${ }^{6}$ (ill. 4), the space around the huge fighting horses is squeezed by a cage so that the action, despite the colossal dynamics, has stopped. This is the image of War, which the artist restrains by literally placing behind lattice walls. A completely different space is created above the cage. This is the image of the World, personified by female figures, standing motionless in the corners and in the center of the cage. They are small. Each of them is a symbol. Youth, a girl with a blossoming bouquet instead of a torso, naked Beloved, pregnant Wife, grieving Mother and Awaiting with a handkerchief in her raised hands. In addition to the image of the World ascended over the image of the War, these figures as allegories of ages also reflect the course of life from dawn to dusk, reflecting the passage of time. Thus, time and space in this composition got an independent sound.

Alexander Burganov loves to visualize the boundaries of space and time. A cage which he sees most often as a shell, the boundary between the body and its environment, is one of the important elements of his work. Thus, he fixates the void created by the escaped body. The Cage ${ }^{7}$ composition (ill. 5) just demonstrates this wonderful artistic technique. A cage with the outlines of a female figure still preserves its forms by the emptiness of its being. There is no body but there is a Soul. The sculptor depicted a fluttering flap and a silhouette of a female hand completely devoid of flesh stretching through the bars inside a cage. The ephemeral and material exchanged places. The body disappeared, the Soul took on a sculptural form. The sculptor captured a moment, an instant, a movement of nothingness.

Alexander Burganov, an artist who has gone through an impressive length of his creative journey from the mid- $20^{\text {th }}$ century to the present day, believes that the creation of an artistic space and the management of cultural time are no less important today than the works of art themselves. They are the main interest, they determine the status and the influence in the space of culture.

Today, the process of creating a work of art is of no less significance than the result. Burganov presents a creative act as the essence and significance of a work of art. Therefore, he considers the finished art form a monumental object created even from paper. Obviously, its existence is limited. However, this, too, is included in the sculptor's concept since it attracts a new category of time for sculpture. In this form of art, which has long been operating with eternal materials, the concept of transience appeared in the description of the lifetime of a work. In 2020, Burganov held a series of expositions where the space of the halls was organized by graphic sheets realized on long paper roll verticals, freely, like columns, standing in space. They combined memories of ancient columns and the ephemeral nature of being, emphasized by material - a light paper sheet. Such penetration of non-eternal materials into the art of sculpture, architecture, and exposure is characteristic of Alexander Burganov's work.

6. War and Peace. Bronze, metal, 1980. The composition was installed in Aachen in front of the European Congress Hall by P. Ludwig.

7. The Cage. Bronze. 1995 


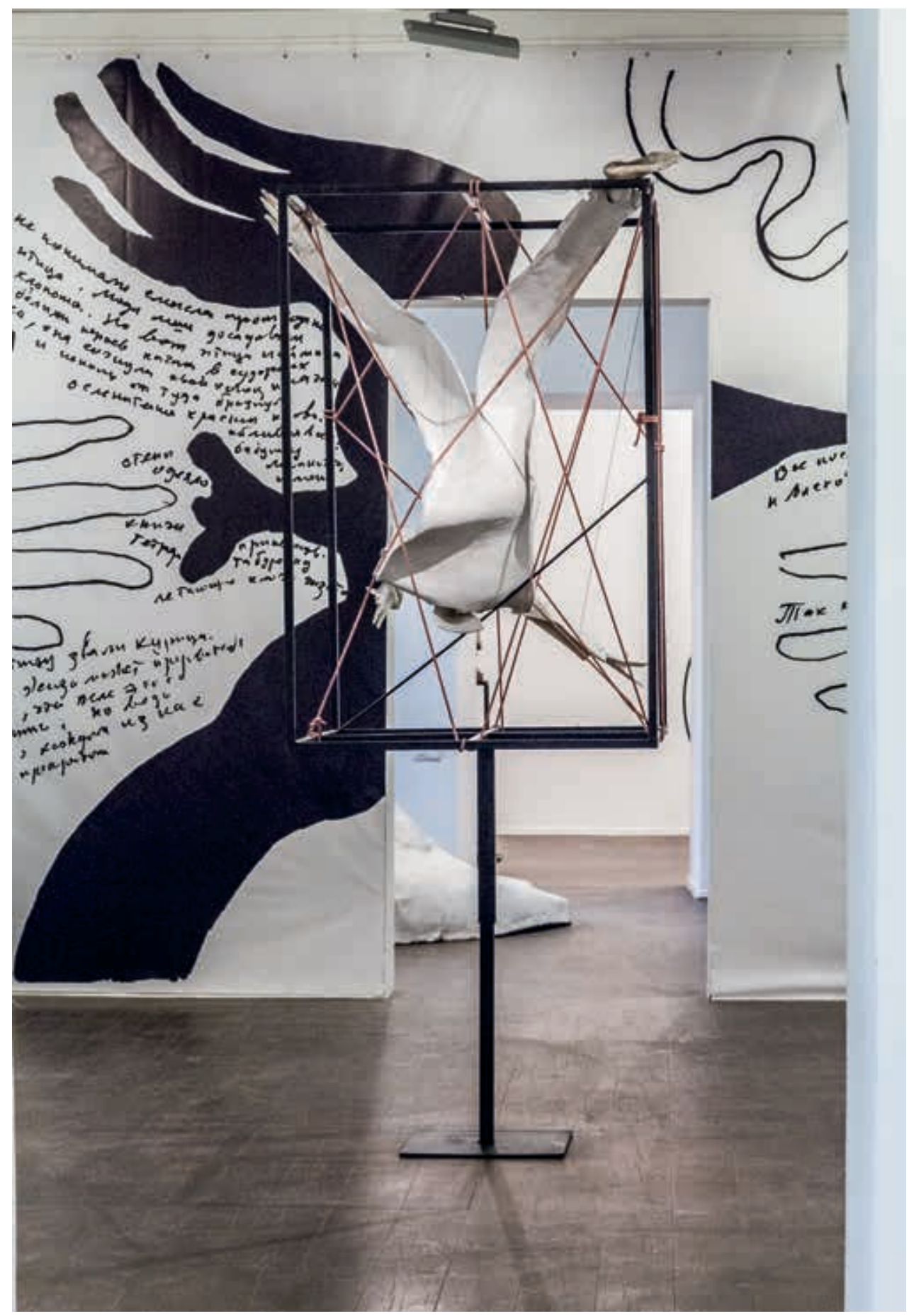

Ill. 6. The Web. Clay, metal, ropes. 2016 


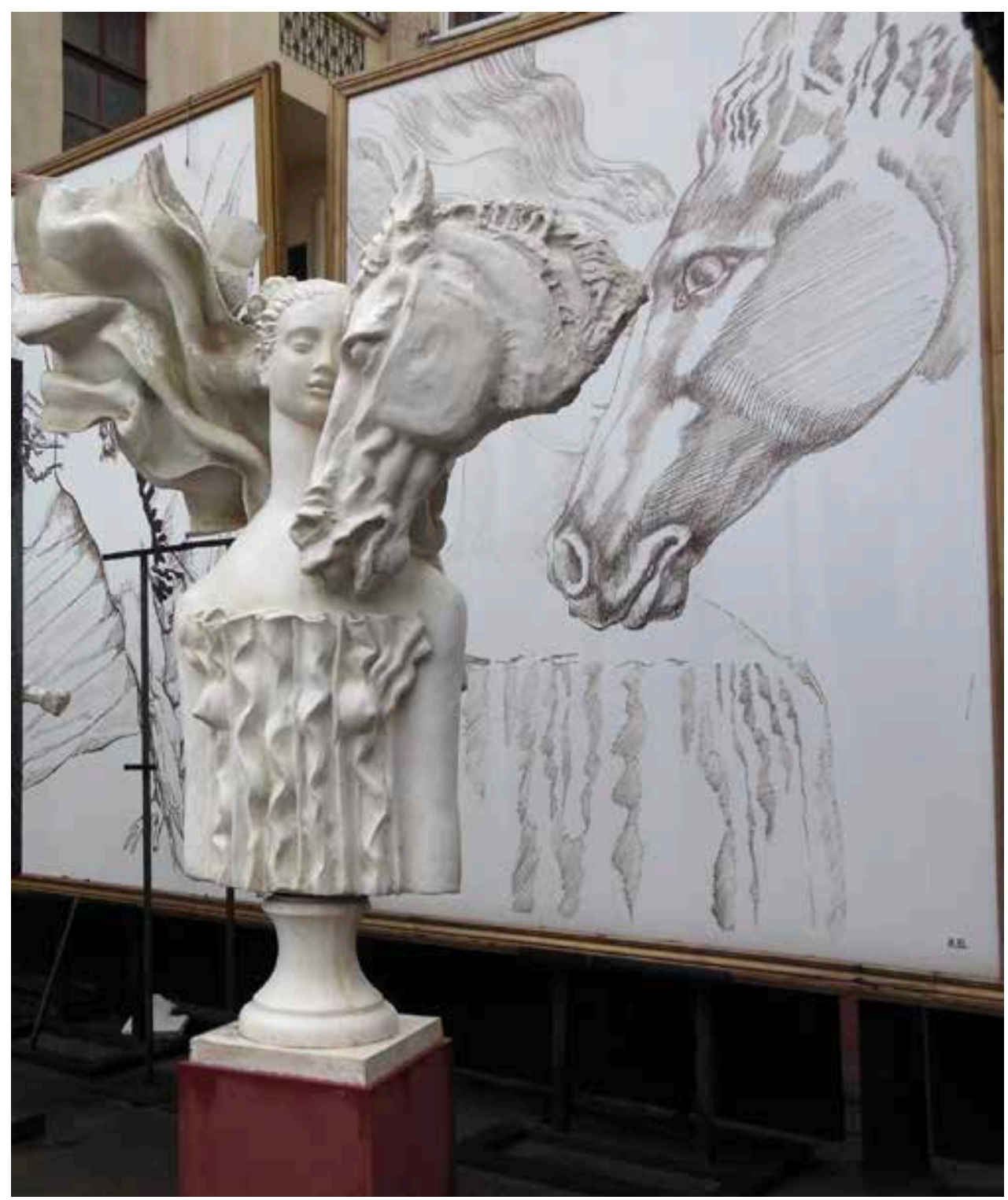

Ill. 7. Exposition of the Moscow State Museum "Burganov House"

The $21^{\text {st }}$ century has brought great changes not only to the form but also to the very substance of the bodies of statues and sculptural compositions. Marble is replaced with plastic, bronze coexists with gypsum, metal meshes surround voids and follow the movements of the wind. Paper on an iron frame is a rightful hero of this "Olympus". It should be noted that there is no place for imitation. New material dictates its conditions for shaping and participates in the interpretation of a new image. 


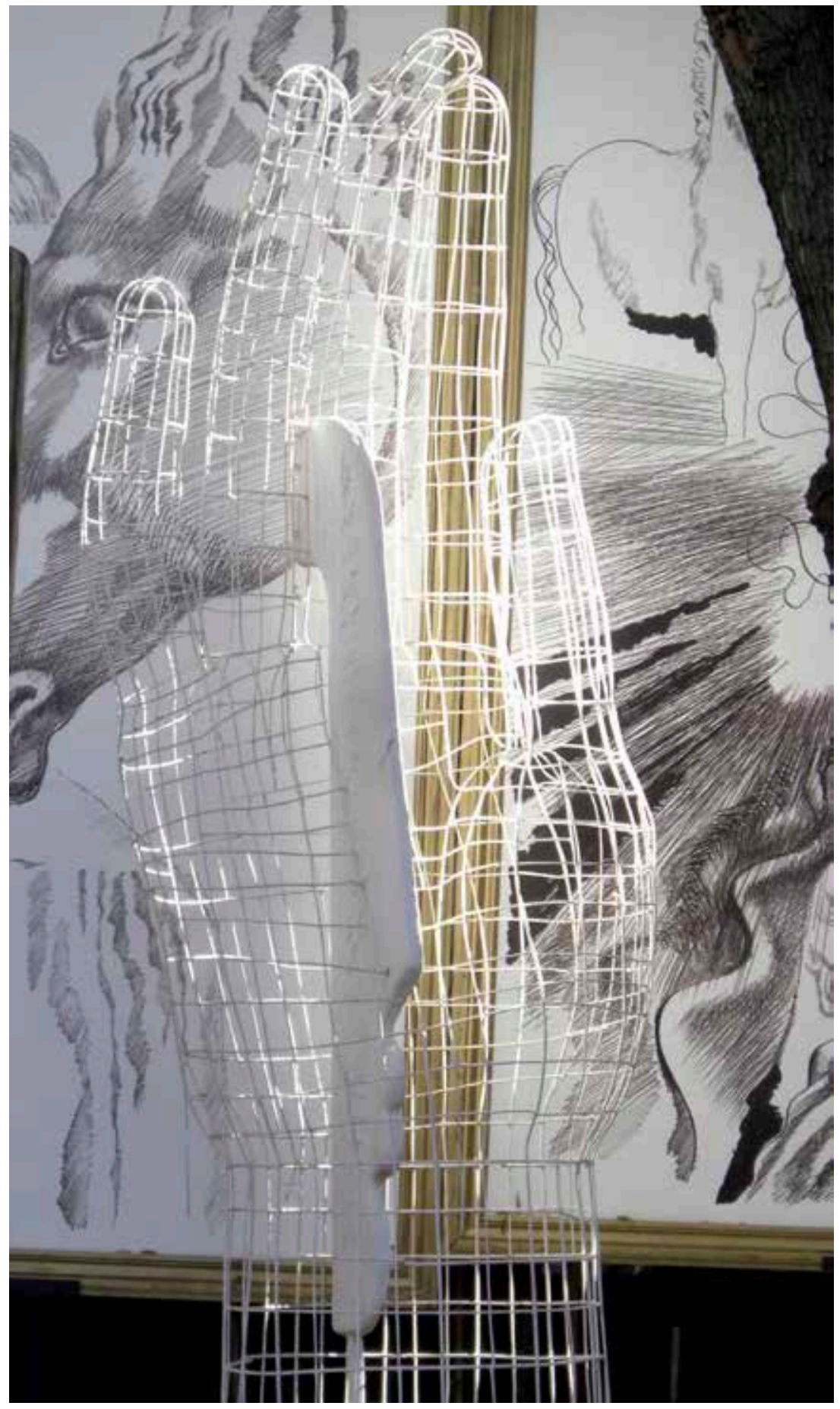

Ill. 8. Exposition of the Moscow State Museum "Burganov House" 
The experiences of European crises brought into art restraint and minimalism, democracy and the idea of a kind of universal permissiveness in the creation and judgments of art. However, the predominance of mass culture, which received a completely new face and opportunity owing to the virtual space, spilled over reality, was the main marker of the culture of the first decades of the $21^{\text {st }}$ century. This new computer paradise, accessible and uncontrollable at the same time, has become an important component of the culture of the $21^{\text {st }}$ century which focuses primarily on the young generation that has presented its requirements for a work of art. Nevertheless, one should not think that this generation is untutored and content with pictures of mass culture. The ability to see and feel high art has not been lost at all. The outward asceticism of the new spectator is deceiving. He or she knows a lot about the luxury of owning unique art but defines it in his or her own way.

Alexander Burganov has created a portrait of a new hero. The $\mathrm{Web}^{8}$ (ill. 6) is a vivid image of a modern person without a face and without a body hanging upside down in a web of wires and threads. With all its being, its paper silhouette is as if the antithesis of the classical museum environment but at the same time it organically exists in it. The composition was created specifically for the exhibition in the Moscow Museum of Modern Art ${ }^{9}$. The walls of the hall where it was exhibited were covered with texts and drawings by A. Burganov from floor to ceiling: fragments of phrases, linear graphics of comics, philosophical parables and ridicule, laughter and cry. These seemingly impossible combinations are authentic to our young contemporary who easily combines trainers with guipure, Mozart with rap, and comics with a high style in art.

The space built by Burganov has strangely connected two inseparable but polar worlds - high and grassroots cultures. They are not antagonists here. Creating his works, Burganov has been able to incorporate the free street style of urban youth culture into the artistic and material form of the compositions. This made it possible to create new sharp emotional images not only in graphics, partly quoting the culture and technique of comics, but also in sculpture. The sculptor easily combines various materials, uses plastic and paper along with traditional classical heavy materials, easily combines and changes spaces. Enlarged by means of billboards to huge sizes, sheets of easel graphics are freely arranged along the streets and in other crowded places (ill. 7, 8). This allowed Burganov to organically fit into the scale of streets and squares, mixing high style and mass culture, arranging his compositions in an urban environment, creating its new art format.

Today, a mixture of styles and cultures, a combination of incongruous is a new reality, introduced into our lives by virtual culture. It is this invisible space that Alexander Burganov could feel and reflect in his work. It made his works relevant and so understandable to the new generation which almost does not feel the classics and loses its cultural identity. We can say that Alexander Burganov's work has become a kind

8. The Web. Clay, metal, ropes. 2016.

9. Alexander Burganov. Magical Realism Exhibition. Moscow Museum of Modern Art, November 2016 - January 2017. 
of bridge connecting the worlds of classics and modernity, high and grassroots culture, myths and reality.

However, it would be naive to think that Burganov is floating on the wave of modern life, only reflecting its realities. He contrasts relaxation and spiritual enlightenment practices, brought into line with the ecology of feelings, values and high-style markers by the new generation, with a dramatic, ragged, stressful image of modernity. Alexander Burganov has built his artistic universe relying on the infinite variability of form, the materialization of non-being, managing time and space, cultural memory and harmony.

\section{REFERENCES}

1. Burganova, M. A. 2015. "Skul'ptor Aleksandr Burganov" ["Sculptor Alexander Burganov"], Nauchno-analiticheskiy zhurnal "Dom Burganova. Prostranstvo kul'tury" [Art, Literature and Music Scientific and Analytical Journal "Burganov House. The space of culture"], no.1, pp. 223-235. (in Russian)

2. Burganova, M. A. 2016. "Skul'ptura Noveyshego vremeni v Muzeye arkheologii Vestfal'skogo universiteta im. Vil'gel'ma v Myunstere" ["Modern Sculpture at the Wilhelm Museum of Archeology of the University of Westphalia in Münster"], Nauchno-analiticheskiy zhurnal "Dom Burganova. Prostranstvo kul 'tury" [Art, Literature and Music Scientific and Analytical Journal "Burganov House. The space of culture"], no. 3, pp. 39-50. (in Russian)

3. Burganova, M. A. 2010. "Syurrealizm. Russkaya traditsiya" ["Surrealism. Russian Tradition"], Nauchno-analiticheskiy zhurnal "Dom Burganova. Prostranstvo kul'tury" [Art, Literature and Music Scientific and Analytical Journal "Burganov House. The space of culture”], no. 4, pp. 34-52. (in Russian)

4. Burganova, M. A. 2017. "From sculpture to installation", Abstract conference "Installation: classic sources and the future", Moscow

5. Burganova, M. A. 2012. Portret i simvol. Monumental'naya skul'ptura Rossii v XX veke [Portrait and symbol. Monumental sculpture of Russia in the twentieth century], Москва

6. Dot, Anna. 2020. "Art and Translation in the Digital Age: Study of El 27\|The 27"th by Eugenio Tisselli”, Barcelona Investigación Arte Creación, v. 8, no. 1, pp. 40-60. DOI: http://dx.doi. org/10.17583/brac.2020.3206. (in Spanish)

7. Doronina, L. N. 2015. "Istoki novogo romantizma v tvorchestve A. N. Burganova" ["The Origins of the New Romanticism in A.N. Burganov's Work], Nauchno-analiticheskiy zhurnal "Dom Burganova. Prostranstvo kul tury" [Art, Literature and Music Scientific and Analytical Journal "Burganov House. The space of culture"], no. 4, pp. 104-113. (in Russian)

8. Zhukovsky, V. I. 2014. "Vizual'noye myshleniye v protsesse khudozhestvennogo tvorchestva" ["Visual Thinking in the Process of Artistic Creation"], Filosofiya i kul'tura [Philosophy and Culture], no. 4, pp. 618-627. DOI:10.7256/1999-2793.2014.4.10770 (in Russian)

9. Portnova, T. V. 2019. “““ [“Alexander Burganov's Sculptural Modifications: on the Theater of Sculpture Exhibition in the Bakhrushin Museum"], Idei $i$ idealy [Ideas and Ideals], vol.11, no.1, part 2, pp. 406-418. DOI: 10.17212 / 2075-0862-2019-11.1.2-406-418 (in Russian)

10. Portnova, T. V. 2018. "Skul'pturnyye obrazy A. Burganova v vizual'no-plasticheskoy teatralizatsii muzeya A.A. Bakhrushina" ["Alexander Burganov's Sculptural Images in the Visual and Sculptural Theatricalization in the Bakhrushin Museum"], V sbornike: Problemy i tendentsii vizual'nykh iskusstv v prostranstve sovremennoy kul'tury. Sbornik nauchnykh trudov. Kafedra iskusstvovedeniya [In the Collection: Problems and Trends of Visual Arts in the Space of Modern Culture. Collection of scientific papers. Art History Department], pp. 95-104. (in Russian)

11. Prozhogina, S. V. 2019. "Zapadnyye vozdeystviya na kul'tury Vostoka: kontakty i konflikty" ["Western Influences on the Eastern Cultures: Contacts and Conflicts"], Orientalistika 
[Orientalism], no.2 (2), pp. 457-471. DOI: 10.31696 / 2618-7043-2019-2-2-457-471 (in Russian)

12. Turchin, V. S. 2015. "Burganovskiye motivy: ataka obrazov, deystvuyushchikh v prostranstve. Dialog s khaosom" ["Burganov Motives: Attack of Images Operating in Space. A Dialogue with Chaos"], Nauchno-analiticheskiy zhurnal "Dom Burganova. Prostranstvo kul 'tury" [Art, Literature and Music Scientific and Analytical Journal "Burganov House. The space of culture”], no. 1, pp. 236-259. (in Russian)

13. Willkens, D. S. 2016. "Reading Words and Images in the Description(s) of Sir John Soane's Museum", Architectural Histories, no. 4(1), p.5. DOI: http://doi.org/10.5334/ah.204 (in English)

14. Chistyakova, M.G. 2012. "Sovremennoye iskusstvo kak kul'turno-antropologicheskiy fenomen" [Contemporary art as a cultural and anthropological phenomenon]. Doctoral Thesis Abstract. Moscow. (in Russia). 
Мария Александровна Бурганова доктор искусствоведения, профессор,

действительный член Российской академии художеств, зав. кафедрой «Монументально-декоративная скульптура» Московская государственная художественно-промышленная академия им. С.Г. Строганова e-mail:dom.text@gmail.com

Россия, Москва

ORCID 0000-0002-8695-9743

ResearcherID C-9437-2017

Юлия Анатольевна Смоленкова кандидат искусствоведения доцент кафедры Монументально-декоративная скульптура Московская государственная художественно-промышленная академия им. С.Г. Строганова e-mail: JSmolenkova@gmail.com Россия, Москва

ORCID 0000-0003-4746-7057

ResearcherID AAB-2212-2019

DOI: $10.36340 / 2071-6818-2020-16-1-19-37$

Александр Бурганов: новый код времени и пространства

Аннотащия. Статья посвящена анализу творчества выдающегося современного скульптора и графика Александра Бурганова. Её основной темой стало исследование категорий Пространства и Времени на примере его произведений. Автор полагает, что Время и Пространство в творчестве А.Н. Бурганова - категории уникальные и менее всего соответствующие реальности, приводит примеры конкретных произведений и убеждает, что скульптурами, графическими произведениями, текстами, инсталляциями и художественными жестами А.Н. Бурганов смоделировал яркий, узнаваемый, уникальный личностный код. Это особенно ощутимо сегодня, когда культура XXI века обострила и почти довела до логического завершения осознание художественного бытия, сформированного во второй половине XX века, и оказалась на пороге новых творческих реалий, повлёкших концептуальные открытия в искусстве. Автор считает, что художник чутко улавливает невидимые волны, излучаемые развивающимися культурами и субкультурами XXI века, в которыX тело, лишенное натуралистической чувственности, сродни античным статуям холодно и символично.

Большое внимание автор уделяет анализу новых материалов в творчестве А. Бурганова, полагая, что XXI век принёс большие изменения не только в фор- 
му, но и в саму субстанцию тел статуй и скульптурных композиций. Мрамор заменяется пластиком, бронза сосуществует с гипсом, металлические сетки окружают пусто́ты и следуют за движениями ветра. Бумага на железном каркасе - полноправный герой этого «Олимпа». Необходимо отметить, что здесь нет места имитации. Новый материал диктует свои условия формообразованию и участвует в трактовке нового образа.

Анализируя современное пространство культуры, автор констатирует, что переживания европейских кризисов принесли в искусство сдержанность и минимализм, демократичность и представление о некой всеобщей вседозволенности в созидании и суждениях об искусстве. Но главным маркером культуры первых десятилетий XXI века стало преобладание массовой культуры, получившей совершенно новое лицо и возможности благодаря виртуальному пространству, разлитому над реальностью. Сегодня смешение стилей и культур, сочетание несочетаемого - новая реальность, внесённая в нашу жизнь виртуальной культурой. Автор подчёркивает, что именно это незримое пространство смог прочувствовать и отразить в своём творчестве Александр Бурганов. Это сделало его произведения актуальными и понятными новому поколению, почти не ощущающему классику. Автор делает вывод, что творчество Александра Бурганова стало своего рода мостом, соединившим миры классики и современности, высокой и низовой культуры, мифов и реальности.

Ключевые слова: Александр Н. Бурганов, скульптор, пространство, время, культура, искусство, авторский стиль.

Александр Бурганов ${ }^{1}$ - мастер, создавший особое мироздание со своими пространственными координатами и временем, текущим в соответствии с его творческим замыслом. Время и пространство в его искусстве - категории уникальные и менее всего соответствующие реальности. Скульптурами, графическими линиями, текстами, инсталляциями, художественными жестами он смоделировал яркий, узнаваемый, уникальный личностный код. Это особенно ощутимо сегодня, когда культура XXI века обострила и почти довела до логического завершения осознание художественного бытия, сформированного во второй половине XX века, и оказалась на пороге новых творческих реалий, повлёкших новые творческие открытия.

Скульптура всегда была связана с отображением человека и создавала его идеальный образ. Свой идеал в фигуративной пластике выстроил и Александр Бурганов. С одной стороны, в нём, как и в античной пластике, видится расставание с реальностью. Художник чутко улавливает невидимые волны новой культуры, излучаемые развивающимися культурами и субкультурами, в которых тело, лишённое натуралистической чувственности, сродни античным статуям холодно и символично. Главное - форма, абстрагированная до идеала. Музы Бурганова стройны, как ионические колонны, в формировании фигур его более интересует

1. Александр Николаевич Бурганов (1935) - российский скульптор, академик Российской академии художеств, народный художник России. Произведения А.Н. Бурганова хранятся в коллекциях крупнейших российских и зарубежных художественных музеев. Его творчеству посвящён Московский государственный музей «Дом Бурганова», находящийся в Москве. 
архитектоника формообразования, нежели телесная чувственность. Символизм образов позволил свободно интерпретировать тело. Руки могут существовать отдельно и множиться, создавая необходимый художнику жест ${ }^{2}$ (илл. 1). Ноги связываются узлом ${ }^{3}$ (илл 2.), бегут по кругу ${ }^{4}$ (илл. 3), даже становятся портретом ${ }^{5}$.

Скульптор создаёт композиции методом коллажа, совмещая разновеликие элементы, цитаты, свободно интерпретируя форму, нанизывая друг на друга и пересекая пространственные и временные слои. В композиции «Война и мир» ${ }^{6}$ (илл. 4) пространство вокруг огромных дерущихся коней сжато клеткой так, что действо, несмотря на колоссальную динамику, остановилось. Это - образ Войны, который художник сдерживает, буквально помещая за решётчатые стены. Над клеткой создано совсем иное пространство. Это - образ Мира, олицетворённый женскими фигурами, неподвижно стоящими по углам и в центре клетки. Они невелики. Каждая из них является символом. Юность - девушка с расцветшим букетом вместо торса, - обнажённая Возлюбленная, беременная Жена, скорбящая Мать и Ожидающая с платком в поднятых руках. Кроме образа Мира, вознесённого над образом Войны, эти фигуры как аллегории возрастов также отражают течение жизни от рассвета до заката, отражая течение времени. Таким образом, время и пространство в этой композиции получили самостоятельное звучание.

Александр Бурганов любит визуализировать границы пространства и времени. Один из важных элементов его творчества - клетка, которую он рассматривает чаще всего как оболочку, границу тела и окружающей его среды. Тем самым он фиксирует пустоту, созданную «сбежавшим» телом. Композиция «Клетка» ${ }^{7}$ (илл. 5) как раз демонстрирует этот замечательный художественный приём. Клетка с очертаниями женской фигуры пустотой своего существа ещё хранит её формы. Тела нет, но есть Душа. Скульптор изобразил внутри клетки трепещущий лоскут и совершенно лишённую плоти силуэтную кисть женской руки, тянущуюся сквозь прутья. Эфемерное и материальное поменялись местами. Тело исчезло, Душа обрела пластическую форму. Скульптор запечатлел миг, мгновение, движение небытия.

Александр Бурганов - художник, прошедший впечатляющий по протяжённости творческий путь от середины XX века до сегодняшнего дня,- считает, что формирование художественного пространства и управление культурным временем сегодня не менее важны, чем сами произведения искусства. Именно они представляют главный интерес, определяют статус и влияние в пространстве культуры.

2. «Цветок». Инсталляция. Пластик. Бронза. 2016;

«Встреча». Инсталляция в ММОМА. Пластик, железо. 2016.

3. «Узел». Бронза, гранит. 2000.

4. «Троянская война». Пластик, металл. 2013. Композиция была создана специально для персональной выставки Александра Бурганова в Музее археологии Вестфальского университета им. Вильгельма в Мюнстере. 2013.

5. «Портрет незнакомки». Бронза. 1980.

6. «Война и мир». Бронза, металл. 1980. Композиция установлена в г. Аахен перед залом Европейских конгрессов П. Людвигом.

7. «Клетка». Бронза. 1995 
Процесс создания произведения сегодня получил не меньшую значимость, чем результат. Бурганов предъявляет творческий акт как сущность и значение художественного произведения. Поэтому законченной художественной формой он считает монументальный объект, созданный даже из бумаги. Очевидно, что время существования его ограничено. Но это тоже входит в концепцию автора, поскольку привлекает новую для скульптуры категорию времени. В этом виде искусства, оперирующем издавна «вечными» материалами, в описании времени жизни произведения появилось понятие быстротечность. В 2020 году Бурганов провёл серию экспозиций, где пространство залов было организовано графическими листами, исполненными на длинных вертикалях бумажных рулонных листов, свободно, словно колонны, стоящими в пространстве. В них соединились воспоминания об античных колоннах и эфемерность бытия, подчёркнутая материалом - лёгким бумажным листом. Такое проникновение «невечных» материалов в искусство скульптуры, архитектуры, экспозиции характерно для творчества Александра Бурганова.

XXI век принёс большие изменения не только в форму, но и в саму субстанцию тел статуй и скульптурных композиций. Мрамор заменяется пластиком, бронза сосуществует с гипсом, металлические сетки окружают пусто́ты и следуют за движениями ветра. Бумага на железном каркасе - полноправный герой этого «Олимпа». Необходимо отметить, что здесь нет места имитации. Новый материал диктует свои условия формообразованию и участвует в трактовке нового образа.

Переживания европейских кризисов принесли в искусство сдержанность и минимализм, демократичность и представление о некой всеобщей вседозволенности в созидании и суждениях об искусстве. Но главным маркером культуры первых десятилетий XXI века стало преобладание массовой культуры, получившей совершенно новые лицо и возможности благодаря виртуальному пространству, разлитому над реальностью. Этот новый компьютерный рай, доступный и неуправляемый одновременно, стал важной составляющей культуры XXI века, которая ориентируется прежде всего на молодое поколение, предъявившее свои требования к произведению искусства. И не следует думать, что оно неискушённо довольствуется картинками массовой культуры. Умение видеть и прочувствовать высокое искусство нисколько не было утрачено. Внешний аскетизм нового зрителя обманчив. Он знает толк в роскоши обладания уникальным искусством, но по-своему определяет его.

Александр Бурганов создал портрет нового героя. «Паутина» ${ }^{8}$ (илл. 6) - яркий образ современного человека без лица и без тела, висящего вниз головой в паутине проволок и нитей. Его бумажный силуэт всем своим существом является как бы антитезой классическому музейному окружению, но при этом органично существует в нём. Композиция была создана специально для выставки в MМоMА 9 Стены зала, в котором она экспонировалась, от пола до потолка были покрыты

8. «Паутина», 2016. Пластик, металл, верёвки.

9. Выставка «Александр Бурганов. Магический реализм». Московский музей современного искусства, ноябрь 2016 - январь 2017. 
текстами и рисунками А. Бурганова: обрывки фраз, линейная графика комиксов, философские притчи и насмешки, смех и плач). Эти, казалось бы, невозможные сочетания аутентичны нашему молодому современнику, легко соединяющему кроссовки с гипюром, Моцарта с рэпом, а комиксы - с высоким стилем в искусстве.

Пространство, выстроенное Бургановым, странным образом соединило два неразрывных, но полярных мира - высокую и низовую культуры. Здесь они не антагонисты. Создавая свои произведения, Бурганов смог включить в художественную и материальную форму композиций свободный уличный стиль городской молодёжной культуры. Это позволило создать и новые острые эмоциональные образы не только в графике, отчасти цитирующей культуру и приём комиксов, но и в скульптуре. Скульптор легко соединяет различные материалы, использует пластик и бумагу наряду с традиционными классическими «тяжёлыми» материалами, легко совмещает и изменяет пространства. Листы станковой графики, увеличенные средствами рекламных билбордов до огромных размеров, свободно расставлены вдоль улиц и в других многолюдных местах (илл. 7, 8). Это позволило Бурганову органично вписаться в масштабы улиц и площадей, смешав высокий стиль и массовую культуру, расположить свои композиции в городской среде, создав её новый художественный формат.

Сегодня смешение стилей и культур, сочетание несочетаемого - новая реальность, внесённая в нашу жизнь виртуальной культурой. Именно это незримое пространство смог прочувствовать и отразить в своём творчестве Александр Бурганов, что сделало его произведения актуальными и столь понятными новому поколению, почти не ощущающему классику и теряющему культурную идентичность. Можно сказать, что творчество Александра Бурганова стало своеобразным мостом, соединившим миры классики и современности, высокой и низовой культуры, мифов и реальности.

Но было бы наивно думать, что Бурганов плывёт на волне современного бытия, лишь отражая его реалии. Расслабленности и практикам духовного просветления, поставленным новым поколением в один ряд с экологией чувств, ценностями и маркерами высокого стиля, он противопоставляет драматичный, рваный, стрессовый образ современности. Александр Бурганов выстроил своё художественное мироздание, опираясь на бесконечную вариабельность формы, материализацию небытия, управление временем и пространством, культурную память и гармонию.

\section{БИБЛИОГРАФИЯ}

1. Бурганова М. А. Скульптор Александр Бурганов // Дом Бурганова. Пространство культуры.-2015.- № 1.- С. 223-235.

2. Бурганова М.А. Скульптура Новейшего времени в Музее археологии Вестфальского университета им. Вильгельма в Мюнстере // Дом Бурганова. Пространство культуры. 2016. - № 3. - C. 39-50.

3. Бурганова М.А. Сюрреализм. Русская традиция // Дом Бурганова. Пространство культуры.-2010.- № 4.- С. 34-52. 
4. Бурганова М. А. 2017. «От скульптуры к инсталляции», Тезисы конференции «Инсталляция: классические истоки и будущее»», Москва

5. Бурганова, М. А. 2012. Портрет и символ. Монументальная скульптура России в XX веке. Москва

6. Доронина Л.Н. Истоки нового романтизма в творчестве А.Н. Бурганова // Дом Бурганова. Пространство культуры. - 2015. — № 4. - С. 104-113.

7. Жуковский В.И. Визуальное мышление в процессе художественного творчества // Философия и культура.— 2014. - № 4. - C. 618-627. DOI: 10.7256/1999-2793.2014.4.10770

8. Портнова Т. В. Пластические модификации А. Бурганова: о выставке «Театр скульптур» в музее А. А. Бахрушина // Идеи и идеалы. - 2019. — Т. 11.— № 1, ч. 2.— С. 406-418. DOI: $10.17212 / 2075-0862-2019-11.1 .2-406-418$

9. Портнова Т. В. Скульптурные образы А. Бурганова в визуально-пластической театрализации музея А. А. Бахрушина // В сборнике: Проблемы и тенденции визуальных искусств в пространстве современной культуры. Сборник научных трудов. Кафедра искусствоведения / отв. ред. Т. В. Малова.- М., 2018. - С. 95-104.

10. Прожогина С.В. Западные воздействия на культуры Востока: контакты и конфликты // Ориенталистика. — 2019. - № 2(2).— С. 457-471. DOI: 10.31696/2618-7043-2019-2$2-457-471$

11. Турчин В.С. Бургановские мотивы: атака образов, действующих в пространстве. Диалог с хаосом // Дом Бурганова. Пространство культуры. - 2015.— № 1.— С. 236-259.

12. Чистякова Марина Георгиевна. Современное искусство как культурно-антропологический феномен: диссертация... доктор философских наук: 24.00.01. - Тюмень, 2012. - 397 с. [Место защиты: Тюменский государственный университет]. - Тюмень, 2012. - 397

13. Dot, Anna. 2020. Art and Translation in the Digital Age: Study of El $27 \|$ The $27^{\text {th }}$, by Eugenio Tisselli // Barcelona Investigación Arte Creación, v. 8, no. 1, pp. 40-60. DOI: http://dx.doi. org/10.17583/brac.2020.3206.

14. Willkens, D. S., 2016. Reading Words and Images in the Description(s) of Sir John Soane's Museum // Architectural Histories, 4(1), p.5. DOI: http://doi.org/10.5334/ah.204 